\title{
Predicting the upper stem diameters and volume of a tropical dominant tree species
}

\author{
Sunita Ulak ${ }^{1} \cdot \operatorname{Keshav}_{\text {Ghimire }}{ }^{1}$ Rabindra Gautam ${ }^{2} \cdot$ Shes Kanta Bhandari $^{2,3}$. \\ Krishna Prasad Poudel ${ }^{4} \cdot$ Yajna Prasad Timilsina $^{2} \cdot$ Dhirendra Pradhan $^{1} \cdot$ \\ Thakur Subedi ${ }^{1}$
}

Received: 18 September 2021 / Accepted: 19 November 2021 / Published online: 4 February 2022

(C) The Author(s) 2022

\begin{abstract}
Predicting upper stem diameters and individual tree volumes is important for product quantification and can provide important information for the sustainable management of forests of important commercial tree species (Shorea robusta) in Nepal. The aim of this study was to develop a taper equation for $S$. robusta. Fifty-four trees were selected and felled in the southern low land of Nepal. A mixed effect modelling approach was used to evaluate 17 different taper functions. 'Leave-one-out cross-validation' was used to validate the fitted taper functions. The variable exponent taper function best fitted our data and described more than $99 \%$ of the variation in upper stem diameters. Results also showed significant effects of stand density on tree taper. Individual tree volume prediction using the local volume model developed in this study was more accurate compared to the volume predicted through the taper function and existing volume model. The taper function developed in this study provides the benefit of predicting upper stem
\end{abstract}

Project funding: The work was supported by a part of the regular program of Forest Research Training Centre (FRTC), Government of Nepal.

Corresponding editor:Tao Xu.

The online version is available at http://www.springerlink.com.

Shes Kanta Bhandari

shes.bhandari@research.uwa.edu.au

1 Forest Research and Training Centre, Kathmandu, Nepal

2 Institute of Forestry, Tribhuvan University, Kathmandu, Nepal

3 School of Biological Sciences, The University of Western Australia, Perth, Australia

4 Department of Forestry, Mississippi State University, Mississippi State, PO Box 9681, Starkville 39762, USA diameter and can be used for predicting volume to any merchantable height of individual trees. It will have implications in estimates of volume, biomass, and carbon and thus may be a potential supporting tool in carbon trade and revenue generation.

Keywords Mixed-model approach - Shorea robusta . Taper $\cdot$ Volume $\cdot$ Nepal

\section{Introduction}

Measurement of individual tree attributes is important for estimating growth and yield as it provides guidelines for decision- making for sustainable forest management (Dau et al. 2015). However, the measurement of all individual tree variables is costly and time-consuming. Diameter at breast height (DBH) and the total height of individual trees are commonly measured variables (Sumida et al. 2013). Compared to DBH, the total height is less frequently measured. Generally, height of sample trees is measured and the height of the rest of the stand is predicted using heightdiameter allometry (Peng et al. 2001; Zhang et al. 2014; Bhandari et al. 2021a, 2021b, 2021c). Although DBH can be measured easily, measurement of the upper stem diameter at a particular height is difficult. Taper equations allow for the prediction of upper stem diameters using easily measured variables such as DBH and total height (Kozak and Smith 1966; Kozak et al. 1969; Kozak 2004; Poudel et al. 2018). A taper equation can directly, or through integration, estimate (1) diameter at any point along the stem, (2) the height at a given diameter, (3) total stem volume, (4) merchantable volume and merchantable height to any top diameter from any stump height, and (5) volumes for logs of any length at any height from the ground (Kozak 
2004; Poudel et al. 2018). Taper in a tree stem is the rate of decrease in stem diameter from base upwards (Chaturvedi and Khanna 2011) and therefore depends on DBH, total height $(\mathrm{H})$ and upper stem height $(\mathrm{h})$. Taper functions vary in their mathematical form; however, a simple taper function can be represented by Eq. 1 .

$d i=f(D B H, H, h i)$

where $d i$ is the stem diameter at height $h i$ above the ground for a tree with a diameter at breast height $(D B H)$ and total tree height $(H)$.

The study of tree taper has a long history. Kozak and Smith (1966) and Kozak et al. (1969) recommended a simple quadratic model for describing tree taper. Bruce et al. (1968) developed a polynomial model for predicting upper stem diameter of red alder (Alnus rubra Bong.). Bennett and Swindel (1972) also used a polynomial equation for the upper stem diameter prediction of slash pine (Pinus elliottii Engelm.). All these taper functions assumed that an entire stem has a single form that can be described with a single function. Consequently, these were referred to as single taper functions (Tang et al. 2017). However, the form of a tree stem varies even within a single tree. The basal portion of the stem resembles the frustum of a neiloid, the middle portion with a paraboloid, and the top portion with a conoid (Husch et al. 1972). Realizing the requirement for three different models for three different portions of the stem of an individual tree, Max and Burkhart (1976) developed segmented taper functions for natural and planted loblolly pines (Pinus taeda L.). The segmented taper functions are more accurate than the single taper function because they consider the variation in tree form at different heights.

Tree form varies among species, individual trees of the same species, and within and between stands as well. To account for such variations, Newnham (1988) and Kozak (1988) introduced a variable-exponent taper function which uses changing exponents to compensate for the changes in the form at different sections of the stem (Perez et al. 1990). Several studies have shown that variable exponent taper functions predict upper stem diameters more accurately than the other two types of taper functions (Sharma and Zhang 2004; Rojo et al. 2005; Duan et al. 2016). However, other studies have also reported that better performance of segmented taper functions over variable exponent taper functions (Crecente-Campo et al. 2009; Özçelik and Crecente-Campo 2016; Shahzad et al. 2021). Several studies have been carried out on tree tapers in different areas of the world (Candy 1989; Fang and Bailey 1999; Kozak 2004; Sharma and Patron 2009; Arias-Rodil et al. 2015; Poudel et al. 2018; Silwal et al. 2018; Alkan and Özçelik 2020; Shahzad et al.2021). Most of studies have taken place in North America (Max and Burkhart 1976; Shaw et al. 2003; Sharma and Patron 2009; Li and Weiskittel 2010; Poudel et al.2018), in Europe (Arias-Rodil et al. 2015; Socha et al. 2020), Asia (Fang and Bailey 1999; Tang et al. 2016; Lumbres et al. 2017; Silwal et al. 2018; Shahzad et al. 2021; Koirala et al. 2021) and relatively a lower number in Australia (Gordon 1983; Bi and Turner 1994; Bi 2000), South America (Nunes and Görgens 2016; Beltran et al. 2017) and Africa (Mabvurira and Eerikäinen 2002; Gomat et al. 2011). To our knowledge, only two taper functions have been developed in Nepal and these were developed for S. robusta C.F. Gaertn. (Silwal et al. 2018) and Tectona grandis L. f. (Koirala et al. 2021).

Tree taper depends on species, site, age, and stand density (Sharma and Zhang 2004; Chaturvedi and Khanna 2011; Duan et al. 2016). These variations require different taper equations and are more important in forests with high degree of species diversity, various management regimes, stand density, and human influence. The tropical forests in the western low land of Nepal are rich in diverse species and are managed under different regimes (community forest, leasehold forest, collaborative forest, religious forest, national forest). S. robusta (family Dipterocarpaceae) is one of the dominant and more important timber species in the tropical forests of Nepal. Its distribution ranges from $120 \mathrm{~m}$ in the southern lowlands to $1200 \mathrm{~m}$ in the middle hills (Jackson 1994; Sah 2000). S. robusta contributes $19.28 \%\left(31.76 \mathrm{~m}^{3} \mathrm{ha}^{-1}\right)$ in total standing volume and $15.27 \%$ in forest type coverage in Nepal (DFRS 2015). S. robusta is a multipurpose species as its stem is used as timber, construction material, and fuelwood (Jackson 1994), leaves as fodder (Kibria et al. 1994) and plates (Kora 2019), and resin as medicine for dysentery and gonorrhea (Joshi 2003). S. robusta forests have the highest total standing volume in Nepal. However, studies in Nepal on the species are limited and mostly focused on volume models (Sharma and Pukkala 1990; Subedi 2017), biomass (Chapagain et al. 2014; Bhandari and Chhetri 2020), form factors (Baral et al. 2020; Chapagain and Sharma 2021; Subedi et al. 2021), regeneration dynamics and diversity (Awasthi et al. 2015, 2020). There is only one study by Silwal et al. (2018) on predicting upper stem diameters of S. robusta. However, their function tested only one form of taper equation, did not consider the effect of stand density, and was based only on 33 individual trees.

The aim of this study was to develop models to predict upper stem diameter and volume of a dominant tree species (S. robusta). Our research questions were: (1) what is the best function to describe tapering in individual trees of $S$. robusta? (2) does stem taper vary with stand density? (3) is the volume predicted using the taper function more accurate than that predicted by the local volume model? and, (4) is 
the volume predicted using the taper function more accurate than that predicted by volume models currently used in Nepal?

\section{Materials and methods}

\section{Study area}

This study used data from a forest of Jogikuti, Shankar Nagar $\left(27^{\circ} 42^{\prime} \mathrm{N}, 8^{\circ} 28^{\prime} \mathrm{E}\right)$, one of the research sites maintained by the Forest Research and Training Centre, (previously known as Department of Forest Research and Survey) of the Government of Nepal, $25 \mathrm{~km}$ northeast of Bhairahawa Airport, Nepal (Fig. 1). The forest was naturally regenerated in 1986 and is dominated by S. robusta or sal. Field measurements were carried out in 2019 when the forest was 33 years old. After a decade of regeneration, stand density was an average of 5200 trees ha $^{-1}$ (Hartz 1997). The soil is loamy and deep with adequate nutrients. The area has a tropical climate with a long-term average annual rainfall of $1649 \mathrm{~mm}, 85 \%$ from June to September (CBS 2019). Longterm rainfall data shows a declining trend. Mean monthly maximum temperature is $31.1{ }^{\circ} \mathrm{C}$ and the mean monthly minimum temperature is $19.2^{\circ} \mathrm{C}$ (CBS 2019). The study site is mostly flat with zero to $5 \%$ slope.

\section{Experimental design}

The research plot covers an area of 92 ha of natural sal forest and is intended to generate information on the growth potential and biomass production of $S$. robusta under different thinning regimes. The experiment was designed in a randomized complete block design (RCBD) with four treatments and three replications. One of the four treatments was a control; data from the control was not included because the trees were not harvested and taper measurements were unavailable. The remaining three treatments were "natural forest with the highest number of stems ha $\mathrm{ha}^{-1}$ (500 trees ha $\left.\mathrm{h}^{-1}, \mathrm{~T} 1\right)$ ", "natural forest with average number of stems ha ${ }^{-1}$ (400 trees ha $\left.{ }^{-1}, \mathrm{~T} 2\right)$ " and "natural forest with the lowest number of stems ha ${ }^{-1}$ (300 trees ha ${ }^{-1}$, T3)" (Table 1). The RCBD design minimized any existing unidirectional variability in the study area. Each plot was $100 \mathrm{~m} \times 100 \mathrm{~m}(1 \mathrm{ha})$, whereas each block covered an area of 4.7 ha. Spacing between the treatments was a minimum of $5 \mathrm{~m}$ buffer on each side. The buffer was also used as a fire line and to make the plot more accessible for silvicultural operations. Spacing between the blocks was at least $50 \mathrm{~m}$.

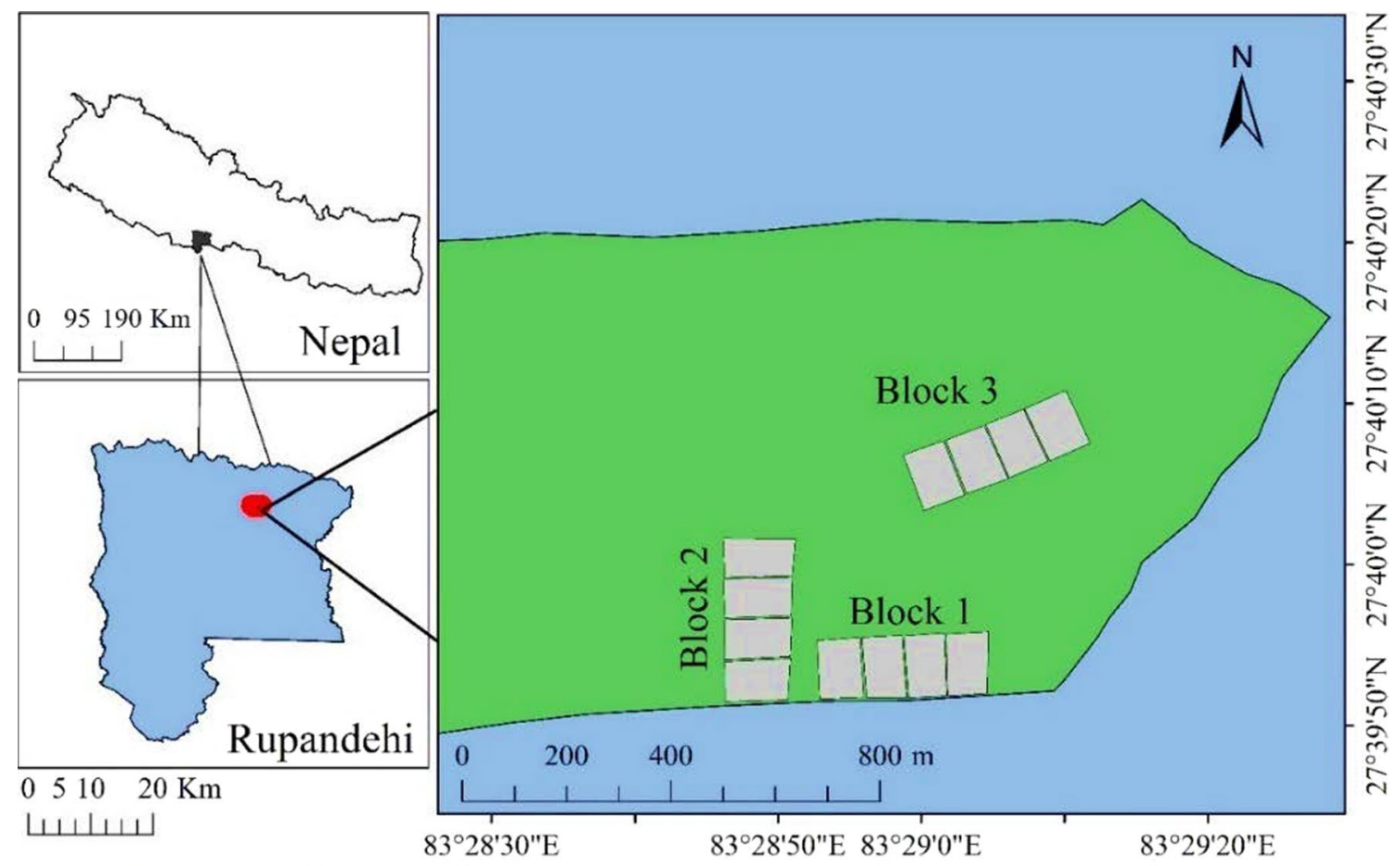

Coordinate System: WGS 1984 UTM Zone 44N

Projection: Transverse Mercator

Datum: WGS 1984

Fig. 1 Map of Nepal showing the study site 


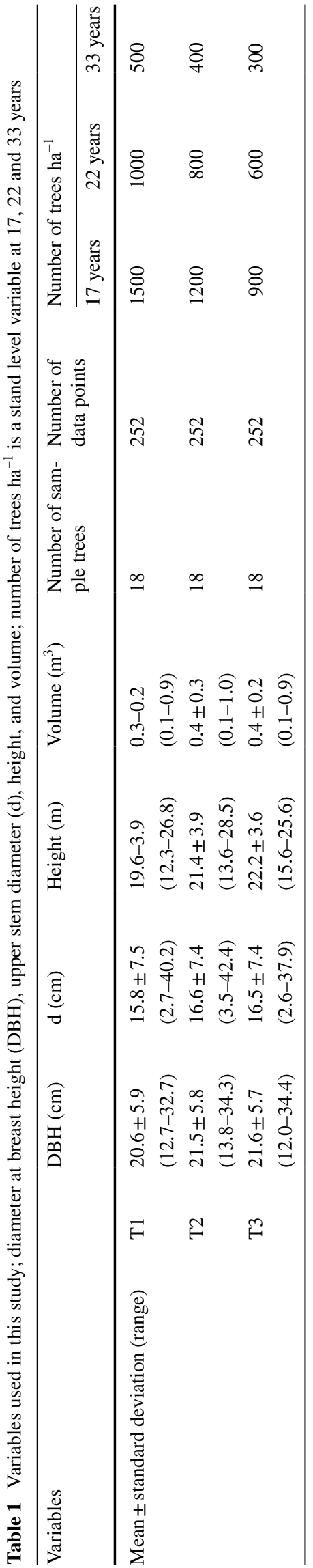

\section{Sampling and measurement}

Fifty-four trees (18 from each treatment) were selected for destructive sampling. The individual trees from each treatment were selected, based on two main criteria. The first was the individual tree must be dominant or co-dominant, the second was the selected dominant or co-dominant trees must be free from disease, decay, and defects on a physical inspection. Once selected, DBH was measured and the tree felled at stump height (at $30 \mathrm{~cm}$ from the ground). Total height was measured with a linear tape, and diameter at 1 , $2.5,5,7.5,10,15,20,30,40,50,60,70,80$, and $90 \%$ of the total height.

\section{Descriptive statistics of the data}

The descriptive statistics of individual trees of all three treatments used in developing taper functions are presented in Table 1. Average DBH was $21.2 \mathrm{~cm}$ and minimum and maximum DBH were 12.0 and $34.4 \mathrm{~cm}$. Average height was $21.1 \mathrm{~m}$, and minimum and maximum heights were 12.3 and $28.5 \mathrm{~m}$. Average volume of the sample trees was $0.4 \mathrm{~m}^{3}$, and minimum and maximum volumes were 0.1 and $1.0 \mathrm{~m}^{3}$. The distribution of $\mathrm{DBH}$ and height showed that the stand was relatively young and had not reached its peak. The scatter plot (not included) of relative diameter and height showed a decreasing trend of diameter with an increase in height.

\section{Model fitting and evaluation}

Seventeen commonly used taper functions were fitted to our data and evaluated for their performance (Table 2). To account for the repeated measurement of diameter at different heights of the same tree, a non-linear mixed effect modelling approach was used. In this approach, DBH, total height $(\mathrm{H})$, and height at which upper stem diameter was measured (h) were considered the fixed effect parameters and the individual-tree variation was considered as random effects. Values of all the parameter and fit statistics were estimated using nlme package (Pinheiro et al. 2018) in Rversion4.0.5 (R Core Team 2021). Wherever available, the published values of parameters were used as the initial values in model fitting to facilitate the fast convergence. Orthogonal polynomials were used for predictor variables to minimize the multicollinearity (Bhandari et al. 2021a, 2021c).The fitted taper functions were evaluated using different criteria, including the significance of estimated parameters (at $5 \%$ level of significance); coefficient of determination $\left(\mathrm{R}^{2}\right.$; higher values indicate better models) (Eq. 2); root mean squared error (RMSE; lower values indicate better models) (Eq. 3) (Montgomery et al. 2001); and Akaike information 
Table 2 Different taper models used in the study

\begin{tabular}{|c|c|c|}
\hline Model & Taper models & References \\
\hline M1 & $d=\sqrt{\beta 0 \times D^{2} \times\left[\frac{h}{1.3}\right]^{2-\left\{\beta 1+\beta 2 * \frac{h}{H}+\beta 3\left(\frac{h}{H}\right)^{2}\right\} \times \frac{H-h}{H-1.3}}}+\varepsilon i j$ & Sharma and Zhang (2004) \\
\hline M2 & $d=D\left\{\beta 0+\beta 1\left(\frac{h}{H}\right)+\beta 2\left(\frac{h}{H}\right)^{2}+\beta 3\left(\frac{h}{H}\right)^{3}+\beta 4\left(\frac{h}{H}\right)^{4}\right\}+\varepsilon i j$ & Ounekham (2009) \\
\hline M3 & $d=\beta 0\left\{1-\left(\frac{h}{H}\right)^{3}\right\}+\beta 1 \ln \left(\frac{h}{H}\right)$ & Pain and Boyer (1996) \\
\hline M4 & $d=D\left\{\beta 0\left(\frac{H-h}{H-1.3}\right)\left(\frac{H}{1.3}\right)^{\beta 1+\beta 2 \frac{h}{H}+\beta 3\left(\frac{h}{H}\right)^{2}}\right\}$ & Sharma and Parton (2009) \\
\hline M5 & $d=\beta 0\left\{\frac{D(H-h)}{H-1.3}\right\}+\beta 1(H-h)(h-1.3)+\beta 2 H(H-h)(h-1.3)+\beta 3(H-h)(h-1.3)(H+h+1.3)+\varepsilon i j$ & Bennett and Swindel (1972) \\
\hline M6 & $d=\sqrt{D^{2}\left(\frac{h}{1.3}\right)^{(2-\beta 0)} \times\left(\frac{H-h}{H-1.3}\right)}+\varepsilon i j$ & Sharma and Oderwald (2001) \\
\hline M7 & $d=\sqrt{D^{2} \times\left\{\beta 0\left(\frac{h}{H}-1\right)+\beta 1\left(\frac{h^{2}}{H^{2}}-1\right)\right\}}+\varepsilon i j$ & Kozak et al. (1969) \\
\hline M8 & $d=\sqrt{D^{2} \times\left\{\beta 0+\beta 1\left(\frac{h}{H}\right)+\beta 2 \frac{h^{2}}{H^{2}}\right\}}+\varepsilon i j$ & Oderwald and Rayamajhi (1991) \\
\hline M9 & $d=\sqrt{D^{2} \times\left\{\beta 0\left(\frac{H-h}{H}\right)+\beta 1\left(\frac{H-h}{H}\right)^{2}\right\}}+\varepsilon i j$ & Oderwald and Rayamajhi (1991) \\
\hline M10 & $d=10^{\beta 0} D^{\beta 1} H^{\beta 2}(H-h)^{\beta 3}+\varepsilon i j$ & Demaerschalk (1972) \\
\hline M11 & $d=\beta 0 D^{\beta 1} H^{\beta 2}(H-h)^{\beta 3}+\varepsilon i j$ & Clutter (1980) \\
\hline M12 & $d=\sqrt{D^{\beta 0} \times\left(\frac{H-h}{H-1.3}\right)^{\beta 1}}+\varepsilon i j$ & Ormerod (1973) \\
\hline M13 & $d=\beta 0\left\{\frac{D(H-h)}{H-1.3}\right\}+\beta 1\left\{\frac{\left(H^{2}-h^{2}\right)(h-1.3)}{H^{2}}\right\}+\varepsilon i j$ & Amidon (1984) \\
\hline M14 & $d=D\left(\frac{H-h}{H-1.3}\right)^{\beta 0}+\varepsilon i j, \beta 0>0$ & Ormerod (1973) \\
\hline M15 & $\begin{array}{l}d=2\left[\frac{\beta 0 D}{1-\exp \{\beta 2(1.3-H)\}}+\left(\frac{D}{2}-\beta 0 D\right) \times\left\{1-\left(\frac{1}{1-\exp (\beta 1(1.3-H))}\right)\right\}\right] \\
{\left[+\exp (-\beta 1 h) \times\left\{\frac{\left(\frac{D}{2}-\beta 0 D\right) \exp (1.3 \beta 1}{1-\exp (\beta 1(1.3-H))}\right\}-\exp (\beta 2 h)\left\{\frac{\beta 0 D \exp (-\beta 2 H)}{1-\exp (\beta 2(1.3-H))}\right\}\right]+\varepsilon i j}\end{array}$ & Riemer et al. (1995) \\
\hline M16 & $d=D \times \sqrt{\beta 0\left(\frac{H-h}{H}\right)+\beta 1\left(\frac{H-h}{H}\right)^{2}+\beta 2\left(\frac{H-h}{H}\right)^{3}}+\varepsilon i j$ & Rentería (1995) \\
\hline M17 & $d=\beta 0+(D-\beta 0) \exp ^{\beta 1(1.3-h)}-\frac{\beta 1}{\beta 1+\beta 2}\left\{\exp ^{\beta 2(h-H)}-\exp ^{\beta 2(1.3-H)+\beta 1(1.3-h)}\right\}$ & Brink and Gadow (1986) \\
\hline
\end{tabular}

$D=$ diameter at breast height, (DBH); $H=$ total height; $d=$ diameter at height $h ; h=$ height of tree from ground where the $d$ is measured; and $\beta 0$, $\beta 1, \beta 2, \beta 3, \beta 4$ are the parameters that were estimated

criterion (AIC; lower values indicate better models) (Eq. 4) (Akaike 1972; Burnham and Anderson 2002). The distribution of residuals was plotted against the predicted upper stem diameter to evaluate whether the taper function had a systematic bias. Residuals were also plotted against the predictor variables and examined for evidence of bias. The best three taper functions were selected using the above evaluation criteria.

$$
\begin{gathered}
R^{2}=1-\frac{\sum_{i=1}^{n}\left(Y_{i}-\hat{Y}_{i}\right)^{2}}{\sum_{i=1}^{n}\left(Y_{i}-\bar{Y}_{i}\right)^{2}} \\
R M S E=\sqrt{\frac{\sum_{i=1}^{n}\left(Y_{i}-\hat{Y}_{i}\right)^{2}}{n}}
\end{gathered}
$$


$A I C=-2 \ln (L)+2 p$

Bias $=\frac{\sum_{i=1}^{n}\left(Y_{i}-\widehat{Y}_{i}\right)}{n}$

$M A E=\frac{\sum_{i=1}^{n}\left|\left(Y_{i}-\hat{Y}_{i}\right)\right|}{n}$

where, $Y_{i}$ and $\widehat{Y}_{i}$ are the observed and predicted values of upper stem diameter, $\bar{Y}_{i}$ the average value of the observed upper stem diameter, $n$ the number of observations, $\ln$ is the natural logarithm, $L$ is likelihood of the fitted taper function and $p$ is the total number of parameters in the taper function; $M A E$ is the mean absolute error.

\section{Effect of stand density on taper}

The method described by Bhandari et al. (2021b) was used to test the effect of stand density on stem tapering. A linear model of upper stem diameter was fitted as a function of height at which the upper stem diameter was measured (h), total height and DBH was allowed to vary with stand density by including an interaction: $\mathrm{d} \sim(\mathrm{h}-+-\mathrm{H}-+-\mathrm{DBH}) * \mathrm{Tr}$, where $\operatorname{Tr}$ was the number of stems per ha (stand density). It was then tested whether the effect of stand density (Tr) was significant in the model.

\section{Validation of taper models}

The leave-one-out cross-validation (LOOCV) method was used to validate the selected taper function. In this method, one observation was left out for validation and $n-1$ observations were used for model fitting, where $n$ is the total number of observations used in data collection. This process was continued $\mathrm{n}$ times until all the observations were used as validation data. The predicted diameter on validation data was plotted against the observed diameter and the fit statistics including $\mathrm{R}^{2}$, RMSE, and mean absolute error (MAE) were estimated.

\section{Volume prediction}

\section{Actual volume calculation}

Diameter at different proportions of total height and length between two consecutive diameter measurement points were recorded for each tree (See "Sampling and measurement" section). From the diameter and length of each section, a separate volume was calculated. Formulae of a cylinder
(Eq. 7) and cone (Eq. 9) were used to calculate the volume of the stump (30 cm height above the ground) and the top section of individual trees, respectively. Volumes of all other sections were calculated using Smalian's formula (Eq. 8), as this is commonly used to estimate the volume of small sections accurately (Avery and Burkhart 1994; Chaturvedi and Khanna 2011; Beltran et al. 2017).

Cylindrical volume $=\frac{\pi D_{1}^{2}}{4} \times L$

Volume by Smalian formula $=\left(\frac{\frac{\pi D_{1}^{2}}{4}+\frac{\pi D_{2}^{2}}{4}}{2}\right) \times L$

Cone volume $=\frac{\pi D_{1}^{2}}{12} \times L$

In these equations, $D_{1}$ is the diameter at the thick end, $D_{2}$ is the diameter at the thin end, and $L$ is the length of the section.

\section{Taper based volume}

Since all the taper equations used in this study do not have a closed form, numerical integration was used to calculate the stem volume of each tree. This method was also followed by Poudel et al. (2018). The total length of the stem was divided into 100 equal sections. The diameters at two ends of those sections were predicted using the fitted taper model, and the volume of each section was calculated using Smalian's formula. Total volume of the tree was obtained by adding the volume of all 100 sections.

\section{Local volume model developed in this study}

The stem volume of each tree was modelled as a function of DBH and total height (Eq. 10). A commonly used power function in the logarithmic form was fitted as this is recommended by several authors for predicting the volume of $S$. robusta in Nepal (Sharma and Pukkala 1990; Subedi 2017). Logarithmic transformation was used because such a model produced smaller residuals than the nonlinear model. The local volume model developed in this study was also validated using LOOCV method.

\section{Volume equation of Sharma and Pukkala (1990)}

Sharma and Pukkala (1990) developed a model using DBH $(D)$ and total height $(H)$ as variables to predict the stem 
volume of individual trees of $S$. robusta in the Nepalese forest (Eq. 11).

$\ln (V)=-9.76124+1.86046 \times \ln (D)+0.99067 \times \ln (H)$

$\ln (V)=-24554+1.9026 \times \ln (D)+0.8352 \times \ln (H)$

For comparison, we predicted the volume using the local volume model developed in this study (Eq. 10), taper equation developed in this study (M1), and models of Sharma and Pukkala (1990) (Eq. 11). Bias (Eq. 5) and RMSE (Eq. 4) were estimated and compared using these equations. The predicted volume was then plotted against $\mathrm{DBH}$.

\section{Results}

\section{Taper functions}

The parameter estimates and fit statistics $\left(\mathrm{R}^{2}, \mathrm{RMSE}\right.$ and AIC) for the seventeen taper functions evaluated in this study are presented in Table 3. Except for $\beta_{1}$ of M16 and $\beta_{2}$ of M17, all other parameters of the 17 taper functions were significant at $95 \%$ confidence level. Therefore, the taper functions M16 and M17were excluded from further analysis. Evaluation based on fit statistics showed that most of the remaining taper functions provided a strong fit except M15 which described only $80 \%$ of the variation in upper stem diameter with comparatively higher RMSE and AIC. Taper function M15 was also excluded from further analysis. The rest of the taper functions explained more than $96 \%$ of the variation in upper stem diameters. M1, M2, and M3 were selected as the best three as they provided higher values of $\mathrm{R}^{2}$ and lower RMSE and AIC values than other remaining taper functions.

The distribution of raw residuals against the predicted upper stem diameter and predictor variables (total height, height at which diameter was measured, and $\mathrm{DBH}$ ) with a smooth superimposed curve for the three best taper functions (M1, M2 and M3) using tree-level random effect is presented in Fig. 2. Plot of residuals against the predicted upper stem diameter and predictor variables did not show any systematic trend in residual distribution. The taper function M1 performed the best with the highest $R^{2}(0.99)$, lowest RMSE (0.57), and lowest AIC (1829). The graph of taper function M1 showed a minimum error with negligible curvature and outliers than other taper functions, suggesting the absence of local bias in this taper function. Therefore, M1 was selected as the best taper function to predict the upper stem diameters of individual trees of $S$. robusta. The predicted upper stem diameters at different tree heights using three best taper functions are presented in Fig. 3a. Stand density had a significant effect on the tapering of the stem of $S$. robusta $(P<0.05)$.

\section{Model validation}

The fit statistics $\mathrm{R}^{2}$ and RMSE of the model fitted with validation data was similar with that of the model fitting data (Fig. $3 b-d$ ). The plot of predicted diameter against the observed diameter and predicted volume against observed
Table 3 Parameter estimates and fit statistics for different taper models used in this study

\begin{tabular}{|c|c|c|c|c|c|c|c|c|}
\hline \multirow[t]{2}{*}{ Taper function } & \multicolumn{5}{|c|}{ Parameter estimates } & \multicolumn{3}{|c|}{ Fit statistics } \\
\hline & $\beta_{0}$ & $\beta_{1}$ & $\beta_{2}$ & $\beta_{3}$ & $\beta_{4}$ & $R^{2}$ & RMSE & AIC \\
\hline M1 & 1.014 & 2.152 & 0.323 & -0.493 & - & 0.9940 & 0.57 & 1829 \\
\hline M2 & 1.169 & -2.650 & 7.351 & -10.547 & 4.862 & 0.9888 & 0.78 & 2162 \\
\hline M3 & 14.317 & -2.447 & - & - & - & 0.9869 & 0.84 & 2386 \\
\hline M4 & 0.375 & -0.155 & 0.483 & - & - & 0.9842 & 0.92 & 2449 \\
\hline M5 & 1.038 & 0.045 & -0.007 & 0.003 & - & 0.9838 & 0.94 & 2316 \\
\hline M6 & 2.133 & - & - & - & - & 0.9817 & 0.99 & 2250 \\
\hline M7 & -1.033 & 10.604 & - & - & - & 0.9745 & 1.17 & 2791 \\
\hline M8 & 1.173 & -1.888 & 0.721 & - & - & 0.9741 & 1.18 & 2553 \\
\hline M9 & 0.477 & 0.693 & - & - & - & 0.9740 & 1.19 & 2547 \\
\hline M10 & 0.128 & 0.995 & -0.785 & 0.717 & - & 0.9722 & 1.23 & 2592 \\
\hline M11 & 1.345 & 0.996 & -0.786 & 0.717 & - & 0.9722 & 1.23 & 2593 \\
\hline M12 & 2.015 & 1.429 & - & - & - & 0.9721 & 1.23 & 2584 \\
\hline M13 & 1.023 & 0.341 & - & - & - & 0.9652 & 1.37 & 2696 \\
\hline M14 & 0.698 & - & - & - & - & 0.9610 & 1.45 & 2694 \\
\hline M15 & 0.04 & -0.09 & 28.36 & - & - & 0.8066 & 3.53 & 2870 \\
\hline M16 & 0.693 & $0.142^{\mathrm{ns}}$ & 0.661 & - & - & 0.9778 & 1.10 & 2496 \\
\hline M17 & -18.809 & 0.025 & $0.039^{\mathrm{ns}}$ & - & - & 0.9661 & 1.36 & 2712 \\
\hline
\end{tabular}

Note ns is non-significant at $95 \%$ confidence level 
Fig. 2 Distribution of residuals against the predicted upper stem diameter $(\mathbf{a}-\mathbf{c})$; total height (d-f); height at which diameter was measured $(\mathbf{g}-\mathbf{i})$; diameter at breast height $(\mathbf{j}-\mathbf{l})$ for the best three taper functions
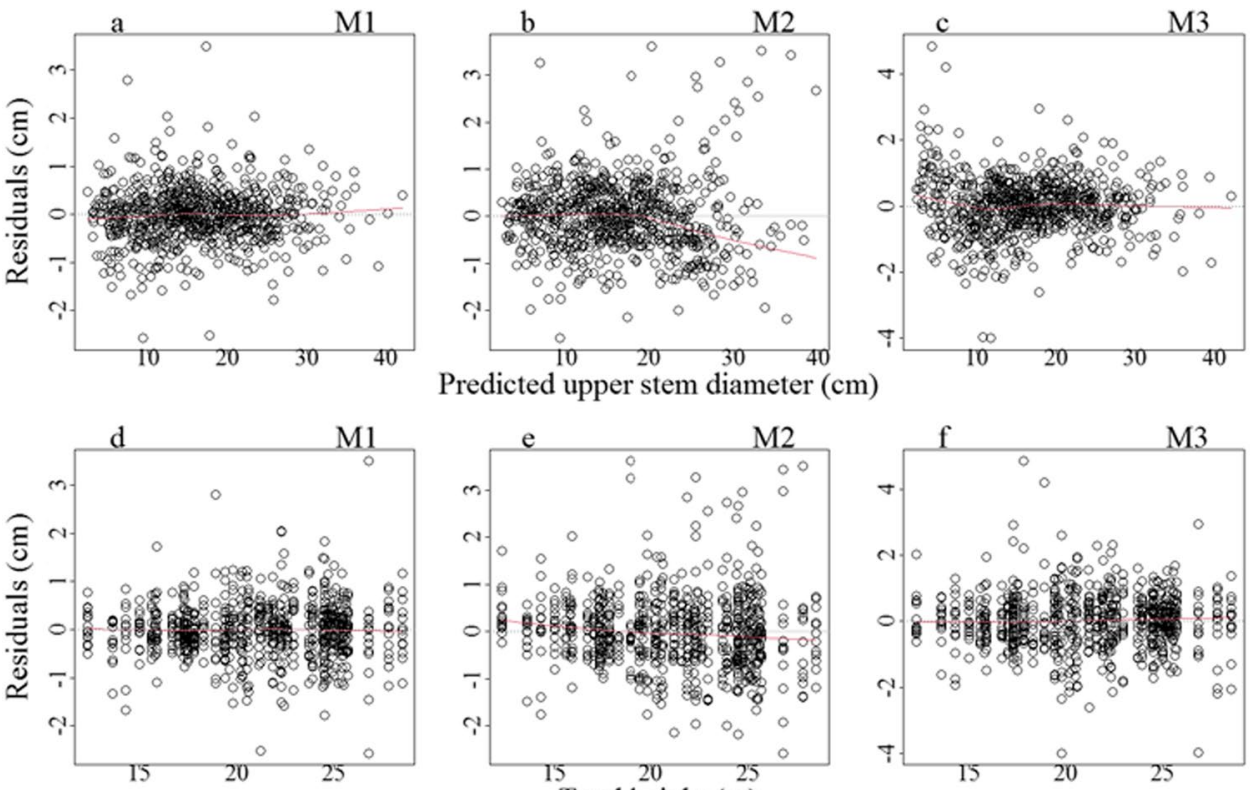

Predicted upper stem diameter $(\mathrm{cm})$
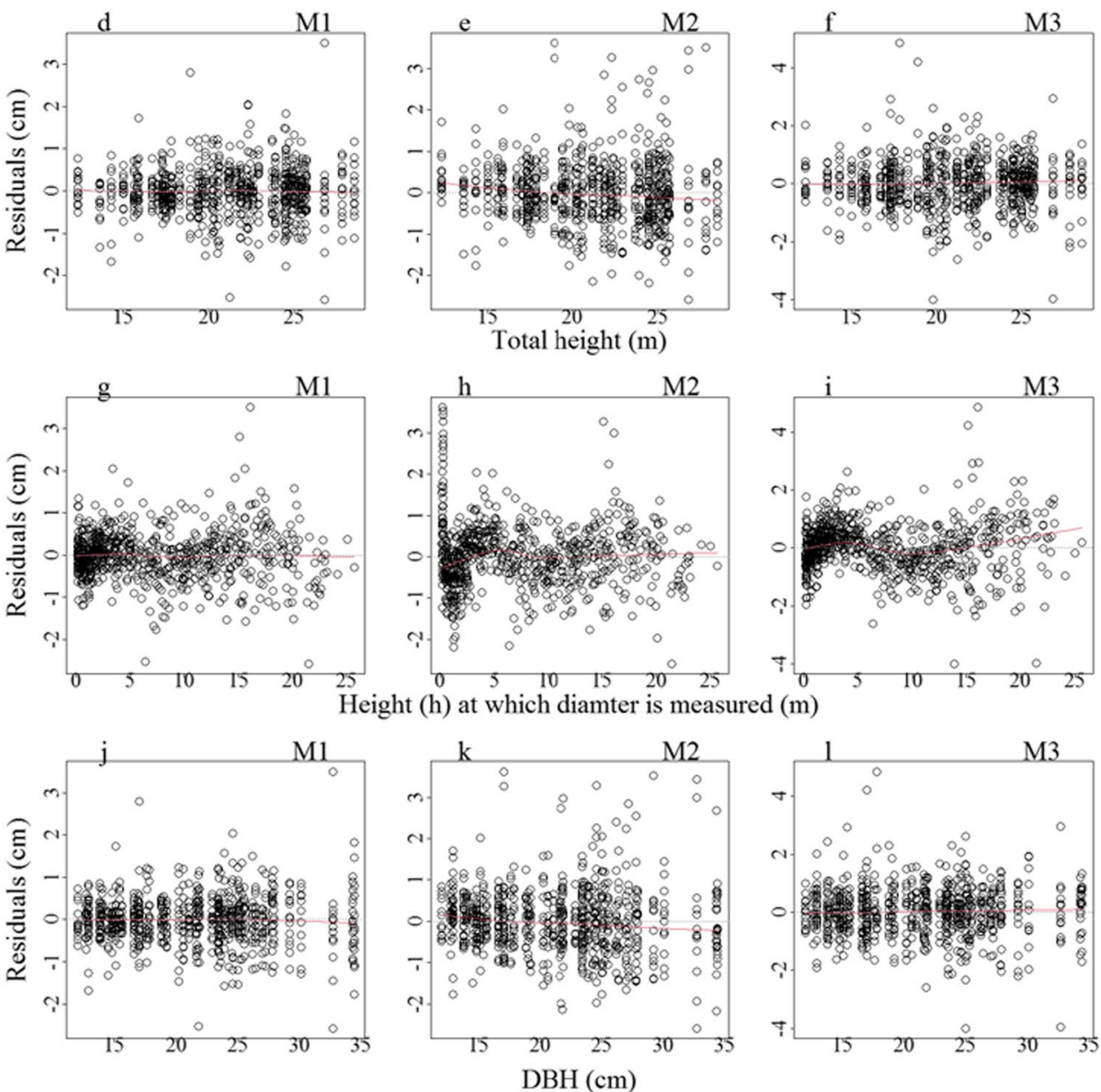

volume further demonstrated that the developed taper and volume models are validated and able to predict upper stem diameters and volume with an acceptable level of accuracy.

\section{Volume prediction}

All parameter estimates of the fitted model were significant at a $99 \%$ confidence level. The model described more than $99 \%$ variation in the total volume of the individual tree (Eq. 10). Validation of this model (Eq. 10) also showed a similar fit statistic (Fig. 4a).

The volume calculated on destructive measurement was considered as a reference volume, and the volume predicted by the local volume model developed in this study, the taper equation developed in this study, and the model of Sharma and Pukkala (1990) were compared with the reference volume. Volume predicted by the local volume model and taper equation showed a positive bias, demonstrating that these two models underestimated the volume of S. robusta. Volume predicted by the Sharma and Pukkala (1990) model had a negative bias, demonstrating an over prediction. The local volume model showed a significantly smaller bias and RMSE compared to the other models (Table 4) and indicates that this model is more accurate in volume prediction. The difference in predicted volume among the models is smaller for small-sized trees and increased with size $(\mathrm{DBH})$ of the 
Fig. 3 Predicted upper stem diameters at different heights using best three taper functions for a Shorea robusta with DBH $32.7 \mathrm{~cm}$ and height $26.8 \mathrm{~m} \mathrm{(a)}$; leave-one-out cross-validation of taper model M1 (b); M2 (c); and M3 (d). $R^{2}$ is coefficient of determination, RMSE is root mean squared error and MAE is mean absolute error. The dotted line in $\mathbf{b}-\mathbf{d}$ is the $1: 1$ reference line
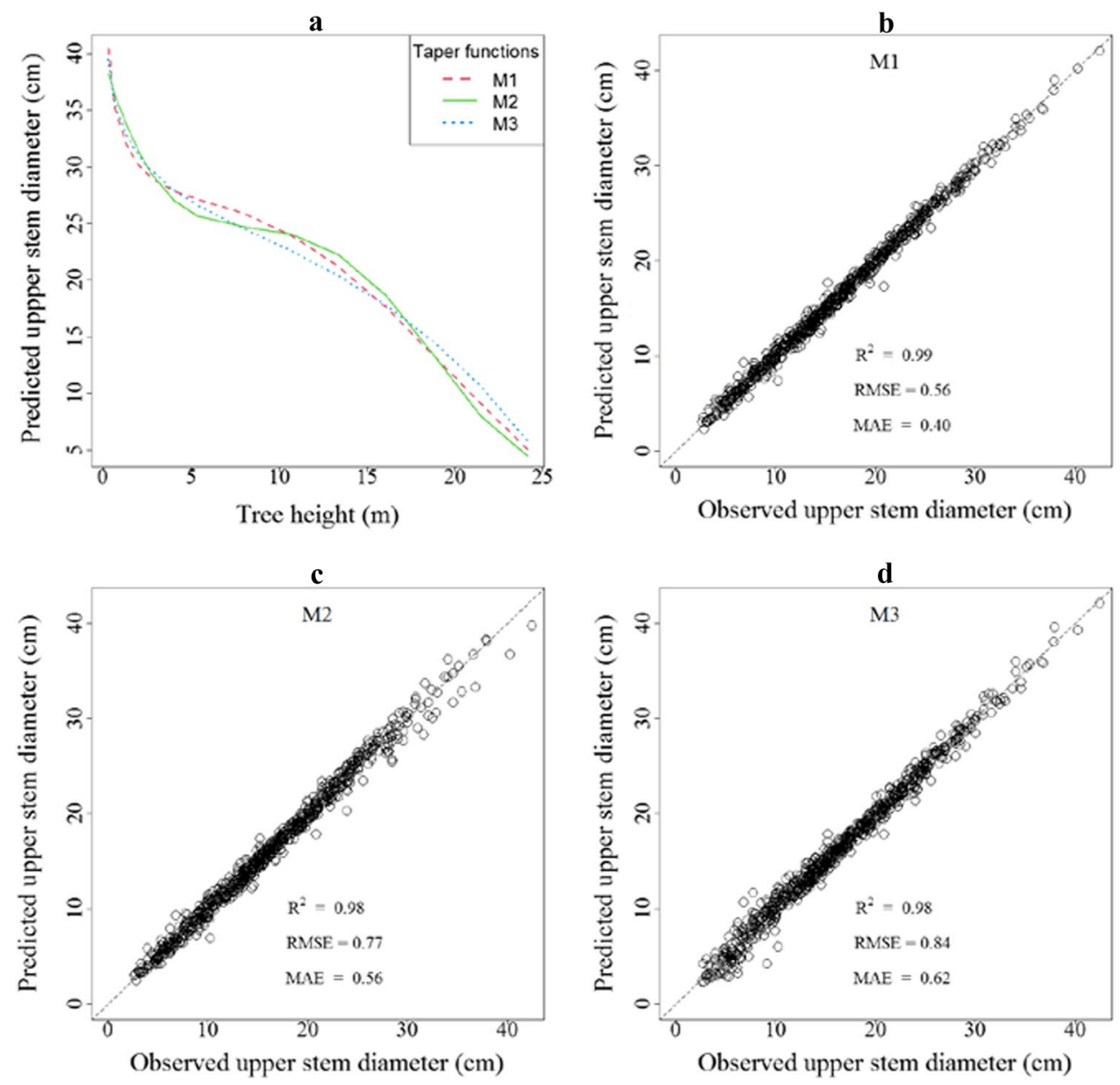

tree (Fig. 4b).The predicted volume of individual trees differed significantly $(P<0.05)$ among three different stand densities (300, 400 and 500 trees per ha) (Fig. 4c, d).

\section{Discussion}

Seventeen taper functions were fitted and evaluated using data collected from 54 felled trees and the best model was selected for predicting upper stem diameters at a given height of S. robusta. The effect of stand density on taper was also examined. In addition, the actual volume of the individual sampled trees was compared with the volume predicted by the integration of the developed taper function, the local volume model and previously developed volume models for S. robusta in Nepal. The main findings indicate that the taper function of $S$. robusta developed using the treelevel random effect in mixed-effect modelling performed well for upper stem diameter prediction. It was also found that stem taper varied significantly with stand density. The merchantable and/or total stem volume of an individual tree can be predicted by integration of the taper function, but the accuracy of the predicted volume is lower compared to the stem volume predicted by the local volume model.

This study showed that the variable-exponent taper function of Sharma and Zhang (2004) performed best in predicting upper stem diameters for S. robusta. This has also been reported as the best function in predicting upper stem diameters of Chinese fir (Cunninghamia lanceolata (Lamb.) Hock.) in southern China (Duan et al. 2016). Several other studies have reported the better performance of variable exponent taper function in comparison to a single form and segmented taper functions (Sharma and Zhang 2004; Rojo et al. 2005; Duan et al. 2016). In contrast, other studies have shown that segmented taper functions are better than variable exponent taper functions (Crecente-Campo et al. 2009; Özçelik and Crecente-Campo 2016; Shahzad et al. 2021), suggesting that a particular form of the taper function may not be universally applicable.

Stand density has a significant effect on the tapering of individual trees of $S$. robusta. Growth in DBH and height of individual trees varies with stand density (Bhandari et al. 2021b). Diameter growth is more sensitive to a reduction in stand density than height. This indicates that diameter growth takes place more rapidly in a stand with low density 
Fig. 4 a Leave-one-out crossvalidation of local volume model; $\mathbf{b}$ comparison of the local volume model with that predicted from the taper equation and Sharma and Pukkala (1990) model; c comparison of the predicted volume by the local volume model among three stand densities; and (d) comparison of the predicted volume by the best taper equation among three stand densities; $R^{2}$ is coefficient of determination, RMSE is root mean squared error and MAE is mean absolute error; the dot line in $\mathbf{a}$ is the 1:1 reference line
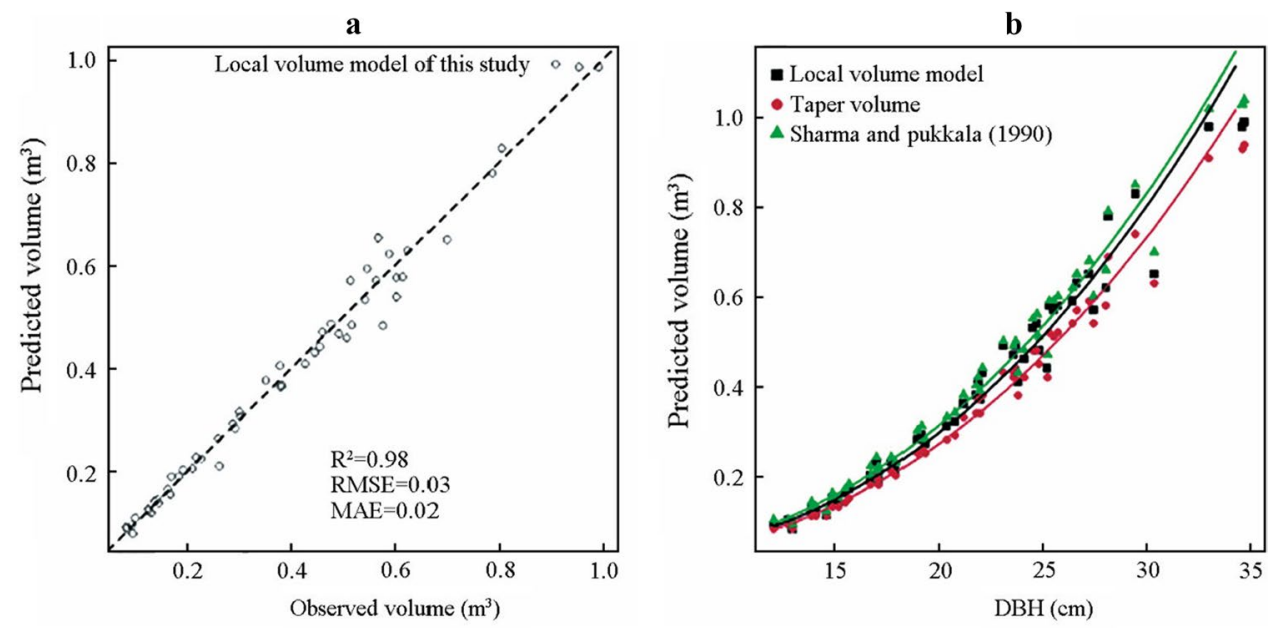

c
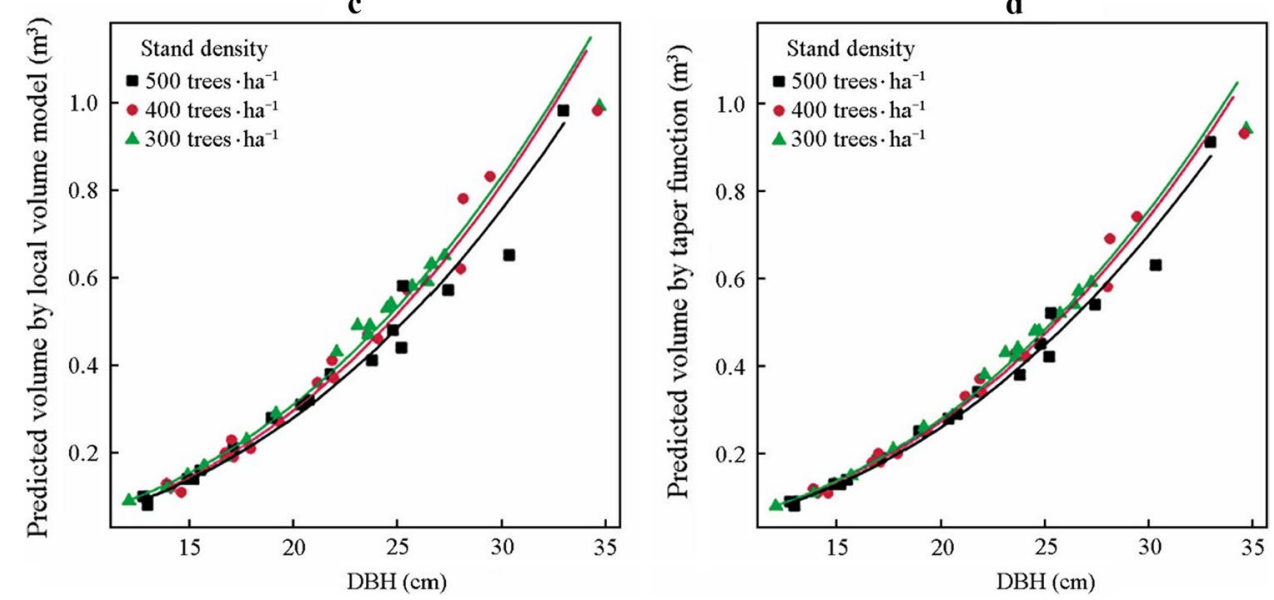

than height. This results in variations in stem form and tapering of individual trees. Variation in stem form due to stand density may be explained by Metzger's theory (Metzger 1893).Individual trees growing in an open stand allocate more resources towards the base of the tree to withstand external forces, including wind (Chaturvedi and Khanna 2011). Allocation of large amounts of resources towards the base of the tree results in a larger base and greater tapering. In contrast, trees growing in a dense stand face a relatively lower magnitude of external forces and avoid the unnecessary allocation of resources towards their base. Individual trees growing in dense stands do not receive sufficient light

Table 4 Mean bias and RMSE for predicting individual tree volume of Shorea robusta using volume model fitted in this study, taper equation, and Sharma and Pukkala (1990)

\begin{tabular}{lcl}
\hline Volume prediction model & Bias $\left(\mathrm{m}^{3}\right)$ & RMSE $\left(\mathrm{m}^{3}\right)$ \\
\hline Local volume model & 0.000056 & 0.0307 \\
Sharma and Pukkala (1990) & -0.0183 & 0.0386 \\
Taper volume prediction & 0.0332 & 0.0489 \\
\hline
\end{tabular}

for growth compared to trees growing in less denser stands. Because of the limited availability of light, trees growing in the dense stands have a tendency of growing upward to receive more light. This results in less tapering and a more cylindrical stem. This study also showed a significant difference in individual tree volumes based on stand density. The difference in individual tree volume between 400 trees $\mathrm{ha}^{-1}$ and 500 trees $^{-1}$ was relatively small but the difference between 300 and 500 trees $^{-1}$ was relatively large (Fig. 4c). The difference between the average volume of trees in the stand with 300 trees ha ${ }^{-1}$ and with 500 trees $\mathrm{ha}^{-1}$ is statistically significant because the difference is $>20 \%$ (Table 1). The differences observed is for stands at age 33 years. As the size and age of the stand increase, the differences in volumes are expected to increase. Trees growing in lower stand density yield higher timber than trees in higher density stands. This will have significant implications in decision- making for forest managers, especially in timber production industries.

Taper functions for tree species of Nepal are limited. Only the taper function developed by Silwal et al. (2018) is available for $S$. robusta which used 33 trees from two 
different sites of the Terai region. Our study has used a relatively larger number of sample trees $(n=54)$. Data collected through destructive sampling is likely to improve accuracy more than data measured from the standing trees, although it increases the cost and time in data collection. Because of the higher accuracy of the data collected through destructive sampling, datasets generated from a small number of trees may be enough to develop the taper model and represent the whole population. Although the number of individual trees felled for data collection was 54, there were 756 data points to fit and evaluate the model. A mixed effect modelling approach was used to account for the correlation associated with multiple measurements taken from the same tree. The mixed effect modelling approach is more appropriate for repeatedly measured data (Lindstrom and Bates 1990).

This study showed that the volume predicted by the local volume model from the same forest and the general volume table developed for the whole of Nepal is more accurate than the volume predicted by the integration of the taper function. This indicates that the taper functions developed in this study are useful tools in predicting upper stem diameters but not in predicting the total stem volume of individual trees. Considering the poor performance of the taper function for total stem volume prediction, it is recommended using the local volume table for the prediction of total stem volume and taper function for the prediction of merchantable volume and/or volume up to a certain height for the stem and upper stem diameter. Poudel et al. (2018) also reported that the volume predicted by local volume models are more accurate than volumes predicted from taper functions developed for Douglas-fir and Western hemlock in the Pacific Northwest of the USA. In a study carried out in Mongolian oak (Quercus mongolica Fisch. ex Ledeb.) in South Korea, Ko et al. (2019) found a significant difference between the volume predicted by existing volume models and taper functions. They recommended using new taper equations to predict the volume by assuming that the forest condition and structure had been significantly changed since the preparation of the existing volume model.

Taper functions can be used as a tool in quantifying timber and other forest products, either from an individual tree or from a stand. These functions also serve as decision support tools in carbon trading and other ecosystem service estimations. Predicting upper stem diameter and stem volume of individual trees provides crucial information to prepare management plans or to implement those plans for sustainable forest management. As the taper function varies with species, stand densities, and management regimes, it is suggested that the development of taper function for each species and management regimes would achieve more accurate prediction and useful information for the sustainable management of forests.

\section{Conclusions}

This study developed a taper function using a non-linear mixed effect model for predicting upper stem diameters of S. robusta, the most important timber species in the southern lowlands of Nepal. The taper function of Sharma and Zhang (2004) performed the best in predicting upper stem diameter among the seventeen candidate functions studied. Stem taper of $S$. robusta varied with stand density. Although the taper function facilitated the prediction of upper stem diameter, total tree volume prediction was not as accurate as that obtained from the local volume equation. The developed taper functions can be used as a tool for estimating volume, biomass and carbon and can provide important information for the sustainable management of the most important commercial tree species ( $S$. robusta) in Nepal. The taper model can be further improved by using data from many individual trees and a wider range of geographical regions and management regimes.

Acknowledgements This study was part of a regular program of the Forest Research and Training Centre (FRTC), Nepal. We would like to acknowledge the FRTC for providing essential resources to accomplish this study and we extend our special thanks to Director General, Dr. Dipak Kumar Kharal and Deputy Director General, Dr. Buddhi Sagar Paudel for constructive suggestions and feedback. We would also thank Mr. Amrit Ghimire and Mr. Rohit Bhusal for their assistance during the field work.

Author contributions The concept of this study was designed by SU and KG. Data were by collected by SU, KG, TS and RG. SKB, KPP and YPT analysed the data. SKB and DP prepared the draft manuscript. All authors thoroughly read and agreed to the published version of the manuscript.

Funding Open Access funding enabled and organized by CAUL and its Member Institutions.

Open Access This article is licensed under a Creative Commons Attribution 4.0 International License, which permits use, sharing, adaptation, distribution and reproduction in any medium or format, as long as you give appropriate credit to the original author(s) and the source, provide a link to the Creative Commons licence, and indicate if changes were made. The images or other third party material in this article are included in the article's Creative Commons licence, unless indicated otherwise in a credit line to the material. If material is not included in the article's Creative Commons licence and your intended use is not permitted by statutory regulation or exceeds the permitted use, you will need to obtain permission directly from the copyright holder. To view a copy of this licence, visit http://creativecommons.org/licenses/by/4.0/.

\section{References}

Akaike H (1972) A new look at statistical model identification. IEEE Trans Automatic Control Ac 19(6):716-723

Alkan O, Özçelik R (2020) Stem taper equations for diameter and volume predictions of Abies cilicica Carr. in the Taurus Mountains, 
Turkey. J Mount Sci 17(12):3054-3069. https://doi.org/10.1007/ s11629-020-6071-x

Amidon EL (1984) A general taper functional form to predict bole volume for five mixed conifer species in California. For Sci 30:166-171

Arias-Rodil M, Diéguez-Aranda U, Puerta FR, López-Sánchez CA, Líbano EL, Obregón AC, Castedo-Dorado F (2015) Modelling and localizing a stem taper function for Pinus radiata D. Don in Spain. Can J For Res 45:647-658

Avery T, Burkhart H (1994) Forest measurements. McGraw- Hill, New York, p 331

Awasthi N, Bhandari SK, Khanal Y (2015) Does scientific forest management promote plant species diversity and regeneration in Sal (Shorea robusta) forest? A case study from Lumbini collaborative forest, Rupandehi, Nepal. Banko Jan 25:20-29. https://doi.org/10. 3126/banko.v25i1.13468

Awasthi N, Aryal K, Chhetri BBK, Bhandari SK, Khanal Y, Gotame P, Baral K (2020) Reflecting on species diversity and regeneration dynamics of scientific forest management practices in Nepal. For Ecol Manag 474:118378. https://doi.org/10.1016/j.foreco.2020. 118378

Baral S, Neumann M, Basnyat B, Gauli K, Gautam S, Bhandari SK, Vacik H (2020) Form factors of an economically valuable sal tree (Shorea robusta) of Nepal. Forests 11(7):754. https://doi.org/10. 3390/f11070754

Beltran H, Chauchard L, Iaconi A, Pastur GM (2017) Volume and taper equations for commercial stems of Nothofagus obliqua and N. alpine. CERNE 23(3):299-309. https://doi.org/10.1590/01047 760201723022330

Bennett FA, Swindel BF (1972) Taper curves for planted slash pine. USDA Forest Service Research Note 179

Bhandari SK, Chhetri BBK (2020) Individual-based modelling for predicting height and biomass of juveniles of Shorea robusta. Aust J For Sci 137(2):133-160

Bhandari SK, Veneklaas EJ, McCaw L, Mazanec R, Renton M (2021a) Investigating the effect of neighbour competition on individual tree growth in thinned and unthinned eucalypt forests. For Ecol Manag 499:119637. https://doi.org/10.1016/j.foreco.2021.119637

Bhandari SK, Veneklaas EJ, McCaw L, Mazanec R, Whitford K, Renton $\mathrm{M}$ (2021b) Effect of thinning and fertilizer on growth and allometry of Eucalyptus marginata. For Ecol Manag 479:118594. https://doi.org/10.1016/j.foreco.2020.118594

Bhandari SK, Veneklaas EJ, McCaw L, Mazanec R, Whitford K, Renton $\mathrm{R}(2021 \mathrm{c})$ Individual tree growth in jarrah (Eucalyptus marginata) forest is explained by size and distance of neighbouring trees in thinned and non-thinned plots. For Ecol Manag 494:119364. https://doi.org/10.1016/j.foreco.2021.119364

Bi HQ (2000) Trigonometric variable-form taper equations for Australian eucalypts. For Sci 46(3):397-409

Bi HQ, Turner J (1994) Long-term effects of superphosphate fertilization on stem form, taper and stem volume estimation of Pinus radiata. For Ecol Manag 70:285-297

Brink C, Gadow KV (1986) On the use of growth and decay functions for modelling stem profiles. EDV Med Biol 17:20-27

Bruce D, Curtis RO, Vancovering C (1968) Development of a system of taper and volume tables for red alder. For Sci 14:339-350

Burnham KP, Anderson DR (2002) Model selection and inference: a practical information-theoretic approach. Springer-Verlag, New York, USA

Candy SG (1989) Compatible tree volume and variable-form stem taper models for Pinus radiata in Tasmania. NZ J For Sci 19:97-111

CBS (2019) Environment statistics of Nepal 2019. Central Bureau of Statistics, Government of Nepal 257-p

Chapagain T, Sharma RP (2021) Modelling form factor for sal (Shorea robusta Gaertn) using tree and stand measures and random effects. For Ecol Manag 482:118807. https://doi.org/10.1016/j. foreco.2020.118807

Chapagain T, Sharma RP, Bhandari SK (2014) Modelling aboveground biomass for three tropical tree species at their juvenile stage. For Sci Tech 10(2):51-60

Chaturvedi AN, Khanna LS (2011) Forest mensuration and biometry. Khanna Bandhu, Dehradun

Clutter JL (1980) Development of taper functions from variable-top merchantable volume equations. For Sci 26:117-120

Crecente-Campo F, Alboreca AR, Dieguez-Aranda U (2009) A merchantable volume system for Pinus sylvestris L. in the major mountain ranges of Spain. Ann For Sci 66:808. https://doi.org/ $10.1051 /$ forest $/ 2009078$

Dau JH, Mati A, Dawaki SA (2015) Role of forest inventory in sustainable forest management: a review. Inter J For Hort 1(2):33-40

Demaerschalk JP (1972) Converting volume equations to compatible taper equations. For Sci 18(3):241-245

DFRS (2015) State of Nepal's Forest. Forest Resource Assessment (FRA) Nepal, Department of Forest Research and Survey (DFRS), Kathmandu, Nepal, p 73

Duan AG, Zhang SS, Zhang XQ, Zhang JG (2016) Development of a stem taper equation and modelling the effect of stand density on taper for Chinese fir plantations in Southern China. Peer J. https:// doi.org/10.7717/peerj.1929

Fang ZX, Bailey RL (1999) Compatible volume and taper models with coefficients for tropical species on Hainan Island in Southern China. For Sci 45:85-100

Gomat HY, Deleporte P, Moukini R, Mialounguila G, Ognouabi N, Saya AR, Vigneron P, Saint-Andre L (2011) What factors influence the stem taper of Eucalyptus: growth, environmental conditions, or genetics? Ann For Sci 68:109-120. https://doi.org/10. 1007/s13595-011-0012-3

Gordon AD (1983) Comparison of compatible polynomial taper equations. NZ J For Sci 13:146-155

Hartz T (1997) Operational forest management plan of the designated Yogikuti, Rupandehi Leasehold Site for Butwal Plywood Factory Pvt. Ltd

Husch B, Miller CI, Beers TW (1972) Forest mensuration. Ronald Press Company, New York, N.Y., p 410

Jackson JK (1994) Manual of afforestation in Nepal. Forest research and survey centre, Kathmandu, Nepal

Joshi K (2003) Leaf flavonoid patterns and ethnobotany of Shorea robusta Gaertn. (Dipterocarpaceae). In: proceedings of international conference on women, science and technology for poverty alleviation (pp. 101-107). WIST, Kathmandu, Nepal

Kibria SS, Nahar TN, Mia MN (1994) Tree leaves as alternative feed resource for Black Bengal goats under stall-fed conditions. Small Rum Res 13:217-222

Ko C, Kang JT, Son YM, Kim DG (2019) Estimating stem volume using stem taper equation for Quercus mongolica in South Korea. For Sci Tech 15(2):58-62. https://doi.org/10.1080/21580103. 2019.1592785

Koirala A, Montes CR, Bullock B, Wagle BH (2021) Developing taper equations for teak (Tectona grandis) trees of central low land Nepal. Trees, For People 5:100103. https://doi.org/10.1016/j. tfp.2021.100103

Kora AJ (2019) Leaves as dining plates, food wraps and food packing material: importance of renewable resources in Indian culture. Bull Nat Res Centre. https://doi.org/10.1186/s42269-019-0231-6

Kozak A (1988) A variable-exponent taper equation. Can J For Res 18:1363-1368

Kozak A (2004) My last words on taper equations. For Chron 80(4):507-515. https://doi.org/10.5558/tfc80507-4

Kozak A, Smith JHG (1966) Critical analysis of multivariate techniques for estimating tree taper suggests that simpler methods are best. For Chron 42:458-463 
Kozak A, Munro DD, Smith JHG (1969) Taper functions and their application in forest inventory. For Chron 45(4):278-283

Li RX, Weiskittel AR (2010) Comparison of model forms for estimating stem taper and volume in the primary conifer species of the North American Acadian Region. Ann For Sci 67:302. https://doi. org/10.1051/forest/2009109

Lindstrom MJ, Bates DM (1990) Nonlinear mixed effects models for repeated measures data. Biometrics 46:673-687

Lumbres RIC, Seo YO, Joo SH, Jung SC (2017) Evaluation of stem taper models fitted for Japanese cedar (Cryptomeria japonica) in the subtropical forests of Jeju Island. Korea For Sci Tech 13(4):181-186. https://doi.org/10.1080/21580103.2017.1393018

Mabvurira D, Eerikäinen K (2002) Taper and volume equations for eucalyptus grandis in Zimbabwe. J Trop For Sci 14(4):441-455

Max TA, Burkhart HE (1976) Segmented polynomial regression applied to taper equations. For Sci 22(3):283-289

Metzger K (1893) Der Wind als maßgebender Faktor für das Wachsthum der Bäume. Mündener Forstl 3:35-86

Montgomery DC, Peck EA, Vining GG (2001) Introduction to linear regression analysis. Wiley, New York, USA

Newnham RM (1988) A variable-form taper function. Can. For. Serv. Petawawa National Forest Institute Information Report PI-X-83.33 p.

Nunes MH, Görgens EB (2016) Artificial intelligence procedures for tree taper estimation within a complex vegetation mosaic in Brazil. PLoS ONE 11(5):e0154738. https://doi.org/10.1371/journal. pone. 0154738

Oderwald RG, Rayamajhi JN (1991) Biomass inventory with tree taper equations. Bio Tech 36:235-239

Ormerod DW (1973) A simple bole model. For Chron 49(3):136-138

Ounekham K (2009) Developing volume and taper equations for Styrax tonkinensis in Laos. M. Sc. Thesis. University of Canterbury New Zealand. 90p

Özçelik R, Crecente-Campo F (2016) Stem taper equations for estimating merchantable volume of Lebanon Cedar trees in the Taurus Mountains. Southern Turkey For Sci 62(1):78-91. https://doi.org/ 10.5849/forsci.14-212

Pain O, Boyer E (1996) A whole individual tree growth model for Norway spruce. In: Workshop IUFRO S5. Nancy: INRI-Nancy. 01-04-Topic 1.

Peng CH, Zhang LJ, Liu JX (2001) Developing and validating nonlinear height-diameter models for major tree species of Ontario's boreal forests. Nor J App For 18(3):87-94

Perez DN, Burkhart HE, Stiff CT (1990) A variable-form taper function for Pinus oocarpa Schiede in Central Honduras. For Sci 36(1):186-191

Pinheiro J, Bates D, DebRoy S, Sarkar D, R Core Team (2018) NLME: linear and non-linear mixed effects models. R package version 3.1-137, URL: https://CRAN.R-project.org/package $=$ nlme

Poudel KP, Temesgen H, Gray AN (2018) Estimating upper stem diameters and volume of Douglas-fir and Western hemlock trees in the Pacific northwest. For Ecosyst 5:16. https://doi.org/10.1186/ s40663-018-0134-2

R Core Team (2021) R: A language and environment for statistical computing. R foundation for statistical computing, Vienna, Austria. URL https://www.R-project.org/

Rentería AJB (1995) Sistema de cubicación para Pinus cooperi blanco mediante ecuaciones de ahusamiento en Durango. Tesis de Maestría en Ciencias. Universidad Autónoma Chapingo. Chapingo, Méx. $77 \mathrm{p}$

Riemer T, Gadow KV, Sloboda B (1995) Ein Modell zur beschreibung von Baumschäften. Allg Forst Jagdztg 166:144-147
Rojo A, Perales X, Sánchez-Rodríguez F, Álvarez-González JG, Gadow K (2005) Stem taper functions for maritime pine (Pinus pinaster Ait.) in Galicia (Northwestern Spain). Eur J For Res 124(3):177186. https://doi.org/10.1007/s10342-005-0066-6

Sah SP (2000) Management options for sal forests (Shorea robusta Gaertn.) in Nepal Terai. Selbyana 21:112-117

Shahzad MK, Hussain A, Burkhart HE, Li FR, Jiang LC (2021) Stem taper functions for Betula platyphylla in the Daxing' an Mountains, northeast China. J For Res 32:529-541. https://doi.org/10. 1007/s11676-020-01152-4

Sharma ER, Pukkala T (1990) Volume and biomass prediction equations of forest trees of Nepal. Forest survey and statistical division, Ministry of forest and soil conservation, Kathmandu, Nepal

Sharma M, Oderwald RJ (2001) Dimensionally compatible volume and taper equations. Can J For Res 31(5):797-803

Sharma M, Parton J (2009) Modelling stand density effects on taper for jack pine and black spruce plantations using dimensional analysis. For Sci 55:268-282

Sharma M, Zhang SY (2004) Variable-exponent taper equations for jack pine, blackspruce, and balsam fir in eastern Canada. For Ecol Manag 198:39-53. https://doi.org/10.1016/j.foreco.2004.03.035

Shaw DJ, Meldahl RS, Kush JS, Somers GL (2003) A tree taper model based on similar triangles and the use of crown ratio as a measure of form in taper equations for longleaf pine. Gen. Tech. Rep. SRS-66. Asheville, NC: U.S. Department of Agriculture, Forest Service, Southern Research Station. 8p

Silwal R, Baral SK, Chhetri BBK (2018) Modelling taper and volume of Sal (Shorea robusta Gaertn. f.) trees in the western Terai region of Nepal. Banko Jan 27:76-83. https://doi.org/10.3126/ banko.v27i3.20544

Socha J, Netzel P, Cywicka D (2020) Stem taper approximation by artificial neural network and a regression set models. Forests 11(1):79. https://doi.org/10.3390/f11010079

Subedi T (2017) Volume models for Sal (Shorea robusta Gaertn.) in far-western Terai of Nepal. Banko Jan 27(2):3-11

Subedi T, Bhandari SK, Pandey N, Timilsina YP, Mahatara D (2021) Form factor and volume prediction equations for individual trees of Shorea robusta in western lowlands of Nepal. Aust J For Sci 138(3):143-166

Sumida A, Miyaura T, Torii H (2013) Relationships of tree height and diameter at breast height revisited: analyses of stem growth using 20-year data of an even-aged Chamaecyparis obtusa stand. Tree Physiol 33(1):106-118. https://doi.org/10.1093/treephys/tps127

Tang XL, Pérez-Cruzado C, Fehrmann L, Álvarez-González JG, Lu YC, Kleinn C (2016) Development of a compatible taper function and stand-level merchantable volume model for Chinese fir plantations. PLoS ONE 11(1):e0147610. https://doi.org/10.1371/ journal.pone.0147610

Tang C, Wang CS, Pang SJ, Zhao ZG, Guo JJ, Lei YC, Zeng J (2017) Stem taper equations for Betula alnoides in South China. J Trop For Sci 29(1):80-92

Zhang XQ, Duan AG, Zhang JG, Xiang CW (2014) Estimating tree height-diameter models with the Bayesian Method. Sci World J. https://doi.org/10.1155/2014/683691

Publisher's Note Springer Nature remains neutral with regard to jurisdictional claims in published maps and institutional affiliations. 